\title{
Analysis of PT Aneka Tambang tbk During Covid Pandemic 19
}

\author{
Anita Munir \\ TANRI ABENG UNIVERSITY \\ Email: munir.anita@tau.ac.id \\ Received: June $2^{\text {nd }} 2020$ \\ Approved: July $27^{\text {th }} 2020$
}

\begin{abstract}
This study aims to predict the performance of PT. Aneka Tambang Tbk during the Covid 19 conditions, as a consideration whether to maintain share ownership to continue investing in 2020. The research method used in this study is a descriptive study method. In this study the author used secondary data by taking PT Aneka Tambang, Tbk Financial Report published from 2015-Q32019. The result could be seen that the net profit margin of PT Aneka Tambang Tbk is low. It causes the company's net profit to be unstable. The decrease in sales it will impact PT Aneka Tambang Tbk's net profit. The volatility of net income makes equity growth not very good. Besides that, the company has an ROE which is still below $10 \%$, which illustrates the company is not very profitable. With the current condition of Covid 19, it is not the right time for shareholders to sell their shares. The author's view is that shareholders should still hold the shares of PT Aneka Tambang Tbk in the hope that nickel prices will increase and will give a positive response to the company. Therefore, shareholders can consider continuing to invest in the long term.
\end{abstract}

Keywords: Fundamental Ratio, Covid 19 and Company Prospect.

\section{Introduction}

The company is established in 1968 as a state-owned company through a merger of several mining companies and government-owned mining projects, which consists of the General Governing Body of the State General Mining Companies, the Indonesian Bauxite Mining Company, the Tjikotok Gold Mining State Company, the Precious Metals State Company, PT Nickel Indonesia, Diamond Project and Bapetamb Projects.

The author conducted research at PT Aneka Tambang because this company is a diversified, vertically integrated, export-oriented mining company that produces a single commodity that is 


\section{Journal of Management and Leadership}

Vol 3, No. 2 November 2020

engaged in activities including exploration, mining, processing and marketing of nickel ore, ferronike, gold, silver, bauxite and coal. In 1999, PT Aneka Tambang began listing for the first time on the Indonesian stock exchange by offering 35\% of its shares to the public. On 29 November 2017, PT Aneka Tambang Tbk has officially become a member of the Mining Industry BUMN Holding together with Inalum, PT Bukit Asam Tbk, PT Timah Tbk with 9.36\% government ownership in Freeport.

PT Aneka Tambang (Persero) Tbk has been listed on the Indonesia Stock Exchange since 1997. The financial performance of a company can not only be seen in financial statements but must be followed by an assessment of financial ratios so that an analysis is needed so that these companies are able to survive in amid the rapid growth of an industry and the company is trying to be motivated to improve its performance. The following is the financial data of PT Aneka Tambang (Persero) Tbk for the last 5 years.

Table 1. Financial Data of PT Aneka Tamban Tbk. (Rp million)

\begin{tabular}{|l|c|c|c|c|c|}
\hline description & \multicolumn{1}{|c|}{2015} & 2016 & 2017 & 2018 & Q3 2019 \\
\hline Asset & $30,356,851$ & $29,981,536$ & $30,014,273$ & $33,306,391$ & $32,655,878$ \\
\hline Bank Payable \& Bonds & $10,110,307$ & $9,904,639$ & $9,398,916$ & $9,921,199$ & $9,858,613$ \\
\hline Retain earning & $9,613,210$ & $9,613,210$ & $9,613,210$ & $10,591,128$ & $10,799,556$ \\
\hline Equity & $18,316,694$ & $18,408,775$ & $18,490,386$ & $19,739,212$ & $19,947,589$ \\
\hline Number of shares outstanding & & & & & \\
& 24,031 & 24,031 & 24,031 & 24,031 & 24,031 \\
\hline Income & $10,531,505$ & $9,106,261$ & $12,653,619$ & $25,241,268$ & $24,537,136$ \\
\hline Gross profit & 195,141 & 851,795 & $1,643,892$ & $3,476,436$ & $3,735,890$ \\
\hline Net profit & $(1,440,852)$ & 64,810 & 136,506 & 874,425 & 561,192 \\
\hline
\end{tabular}

The data in the table above shows that the company's sales data from 2015 to 2016 has decreased, but in 2017 it has increased. Meanwhile, the company's equity and net income received increased until the end of 2018. On a year-to-date basis, the company's assets decreased by $2 \%$, from 33.3 trillion at the end of 2018 to 32.6 trillion in Q3 2019. Bank loans and bonds decreased slightly by $1 \%$ from the previous 9.9 trillion to 9.8 trillion.

The current situation of the Covid 19 pandemic can certainly affect the financial performance of PT Aneka Tambang (Persero) Tbk. Based on the data and description above, researchers are interested in conducting research with the title Influencing the Covid 19 pandemic against PT Aneka Tambang Tbk. This study also aims to determine the financial ratios that include leverage 
and profitability at PT Aneka Tambang (Persero) Tbk and to predict the company's value investing based on its Market Value analysis.

\section{Literature Review}

The company financial report presented is a form of accountability of each management in the company and to the parties concerned in the company. Financial statements aim to provide information and descriptions of financial position and company performance that can be used as a guide in making business decisions. Financial ratio analysis is a number that shows the relationship between an element and other elements in the financial statements. The relationship between the elements of the financial statements is expressed in a simple mathematical form. Individually the ratio is small except when compared to a standard ratio that is worthy of being the basis of comparison.

Kasmir (2010), the components contained in the financial statements consist of balance sheets, income statements, reports of changes in capital, cash flow statements, and notes to financial statements.

Agnes Sawir (2015) said that profitability ratios are ratios used to measure a company's ability to earn profits or profits. The profitability of a company embodies a comparison between profits and assets or capital that produces these profits. In addition, profit margin is a comparison between net sales minus the cost of goods sold at the level of sales. This ratio describes the gross profit that can be achieved from the number of sales. Return on assets which is also a ratio used to measure the ability of invested capital in all assets to generate net profits. Return on equity is a ratio used to measure the ability of own capital to generate profits for all shareholders, both ordinary shares and preferred shares.

Harahap (2011), Parties with an interest in financial reports are shareholders, investors, capital market analysts, managers, employees, tax agencies, creditors, suppliers, government, customers or consumer institutions, non-governmental organizations and researchers or academics.

Gibson C (2012), price earnings ratio (PER) is one of the most basic measures in fundamental stock analysis. In simple terms, PER is a comparison between the share price and the company's net profit. Because the focus of the calculation is the net profit that has been generated by the company, then by knowing PER of an issuer, we can know whether the price of a stock is reasonable. Furthermore, enterprise value is a number that shows the value of a company or firm value, so EV is similar to Market capitalization

\section{Research Methodology}

This type of research is descriptive research. Nazir (2011) argues that descriptive research is a method of examining the status of a group of humans, an object, a set of conditions, a system of thought, or a class of events in the present. The aim is to make systematic, factual and accurate descriptions, descriptions or paintings of the facts, characteristics and relationships between the phenomena being investigated. Researchers have chosen this type of research because it is 
considered the most appropriate, namely describing systematically, factually, and accurately about the conditions to be studied based on data in the form of numbers and studying specifically an object at PT Aneka Tambang Tbk which has been listed on the Indonesia Stock Exchange, especially on the company's financial performance.

This research is a case study of PT Aneka Tambang Tbk, by designing a frame work model in making investment decisions in companies that are expected to be profitable after being analyzed. It is quantitative research by using descriptive statistical analysis. Sekaran (2013), the purpose of descriptive research is to give researchers a history or to describe aspects that are relevant to the phenomenon of attention from a person's perspective, organization, industry orientation, or others, which then helps researchers provide ideas for further investigation and research certain simple decisions.

\section{Result}

\section{Fundamental Analysis}

Year to date, the assets of PT Aneka Tambang Tbk have decreased by 2\%, from 33.3 trillion at the end of 2018 to 32.6 trillion in Q3 2019. So that it can be projected that by the end of 2019 the assets of PT Aneka Tambang Tbk will remain compared last year amounted to 30 trillion. Bank loans and bonds decreased slightly by $1 \%$ from the previous 9.9 trillion to 9.8 trillion.

Table 2.

\begin{tabular}{|c|c|c|c|c|c|}
\hline Ratios & 2015 & 2016 & 2017 & 2018 & Q3 2019 \\
\hline DER & $55.20 \%$ & $53.80 \%$ & $50.83 \%$ & $50.26 \%$ & $49.42 \%$ \\
\hline
\end{tabular}

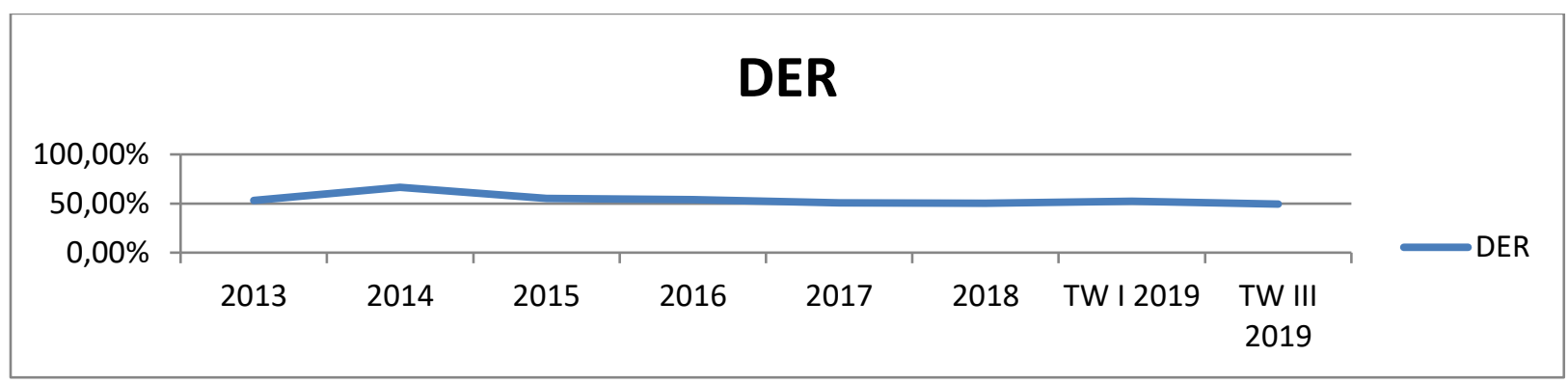

Chart 1, processed by author

The lower the debt to equity ratio shows a good performance for the company. This bank loan represents a DER of $49.4 \%$ at Q32019. On the equity side attributable to the owner of the parent company, PT Aneka Tambang Tbk recorded an increase in equity of 1\%, from 19.7 trillion to 19.9 trillion. And based on the historical growth of PT Aneka Tambang Tbk's equity, it can be projected that until the end of 2019, PT Aneka Tambang Tbk's equity will increase by around 1\% - $2 \%$ compared to the 2018 period. 


\section{Journal of Management and Leadership}

Vol 3, No. 2 November 2020

The higher the net profit margin, the better the company's financial performance. PT Aneka Tambang Tbk's revenue increased by 23\% to 24.5 trillion in Q3 2019 from 19.9 trillion in Q3 2018. So based on historical data, it can be projected that until the end of 2019 PT aneka Tambang's revenue will increase by around $8 \%-9 \%$. However, it is unfortunate that the increase in PT Aneka Tambang Tbk's income was not accompanied by an increase in net profit, this is because the cost of goods sold has increased significantly, which causes the gross profit of PT Aneka Tambang Tbk to decrease. Apart from that, the net profit attributable to the owner of the holding entity, PT Aneka Tambang Tbk, has a net profit that has decreased by $11 \%$ in the third quarter of 2019. From the previous 631 billion last year to 561 billion this year. Therefore, the projected net profit until the end of this year will decrease $10 \%$ compared to last year.
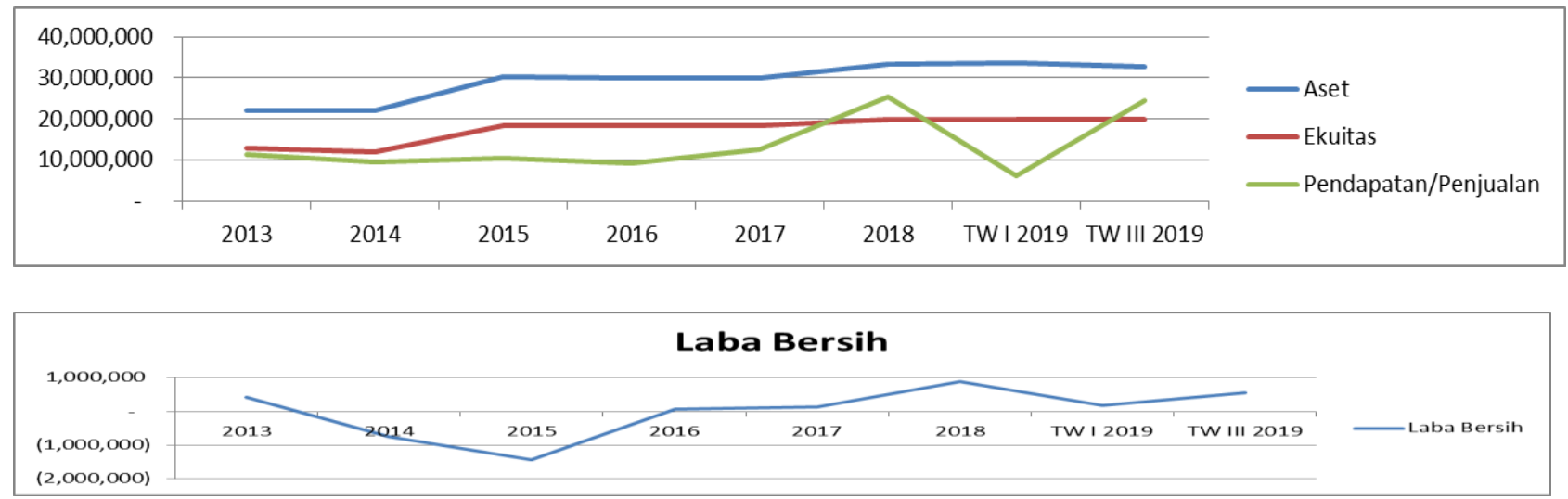

Table 3.

\begin{tabular}{|l|l|l|l|l|}
\hline Ratios & 2015 & 2016 & 2017 & 2018 \\
\hline ROE & $-7,87 \%$ & $0,35 \%$ & $0,74 \%$ & $4,43 \%$ \\
\hline PBV & 0,41 & 1,17 & 0,81 & 0,93 \\
\hline Price & 314 & 895 & 625 & 765 \\
\hline
\end{tabular}

Prior to 2016, the share price of PT Aneka Tambang Tbk was always traded at PBV less than 1x. Most likely because at that time PT Aneka Tambang's ROE was always negative. Starting from 2016 to 2018, when PT Aneka Tambang started to book a net profit and PT Aneka Tambang's ROE began to be positive, PT Aneka Tambang's share price began to trade at the PBV level of 0.8 - 0.9 times. The thing that needs attention is PT Aneka Tambang's very small Net Profit Margin, which is only 3\%, where sales of 6.2 trillion only resulted in a net profit of 171 billion. Even in 2017 PT Aneka Tambang's Net Profit Margin was only 1\% (sales of 12.6 trillion resulted in net profit of only 136 billion). At the close of 2018, PT Aneka Tambang's shares closed at the price of 765 which shows the PBV label of $0.81 x$.

\section{Covid 19 and shares prospect}

Citing the publication of the company's financial reports, almost all companies find it difficult to predict the long-term impact of the pandemic sentiment on the company's operational performance. However, various signs of a potential slowdown in the company's performance this year have begun to appear. According to Indonesia Stock Exchange Information, in the first 
quarter of 2020, global gold prices continued to show a strengthening trend, namely successfully increasing 7.5 percent and touching the highest level since 2013 at the level of US \$1,700 per troy ounce. In addition, in the first quarter of 2020, the rupiah weakened significantly against the US dollar and caused the company to record a higher foreign exchange loss compared to the same period last year. Rising gold prices in recent trades will limit consumer interest in buying physical gold. Meanwhile, the price of nickel is inversely proportional to weakening by 19.89 percent and touched the lowest level at US \$10,867 per ton, compared to last year's closing price of US \$14,000 per ton.

\section{Conclusion and Recommendation}

With less strong fundamental conditions, it can be seen from the small net profit margin, which causes the company's net profit to be unstable. This risk occurs because the decline in sales will have an impact on the net profit of PT aneka Tambang, tbk. The volatility of net income makes equity growth not very good. In addition, PT Aneka Tambang Tbk has a small ROE below 10\%, with a small ROE which describes the company as not very profitable. Besides, a stronger gold price can lead to weakening demand for physical gold. Meanwhile, the low nickel price can erode the company's margins, so that the revenue is likely to be corrected too. The current impact of Covid 19, it is possible that the sales performance of PT aneka Tambang tbk will not move better than last year, but also not worse than last year. So it is likely that it will tend to be flat this year, because physical gold consumption will decrease along with the expensive price. In addition, maintaining the nickel export market, especially in the East Asia region, will have a positive impact on the company's performance.

Even though the company's performance is not good enough, now is not the right time for shareholders to release the shares. The author's view is that shareholders should still hold the shares of PT Aneka Tambang Tbk. Based on the review above, it is estimated that the share price will rise, so it is better if shareholders hold it for the long term.

\section{References}

Bursa Efek Indonesia. www.idx.co.id

IAI. (2012). Pernyataan Standar Akuntansi Keuangan. Salemba. Jakarta.

Kasmir (2008). Manajemen Perbankan.Jakarta: PT Raja GrafindoPersada

Nazir, Mohammad (2011). Metode Penelitian. Cetakan Ketujuh. Bogor: Ghalia Indonesia.

Sekaran, Uma. (2013). Metodologi Penelitian untuk Bisnis, Buku 1, Edisi 4. Salemba. Jakarta.

Gibson, C., (2013). Financial Reporting and Analysis. 13th Edition, South-Western. 
Journal of Management and Leadership

Vol 3, No. 2 November 2020

Agnes Sawir, (2015). Analisa Kinerja Keuangan dan Perencanaan Keuangan Perusahaan, PT Gramedia Pustaka, 2005:129.

Charles H. Gibson (2012). Financial reporting_and_analysis 13 th edition. Boston Massachusetts: Cengage Learning. 